\title{
Finite Element Modeling of Wing Bird Strike
}

\section{Marinko Ugrčić \\ Associated Professor Economic Institute in Belgrade}

Stevan M. Maksimović

Full Professor

Military Technical Institute in Belgrade

\section{Dragi P. Stamenković \\ Assistant Professor \\ Termoelektro-projekt, Belgrade}

\section{Katarina S. Maksimović}

Assistant Professor

Secretariat for Utilities and Housing Services Water Management, Belgrade

\section{Khettou Nabil}

Phd Student Military Academy, Belgrade. Faculty of Engineering Sciences, Université Saâd Dahleb Blida

Bird strike events are a potential dangerous problem faced by flight safety nowadays. These events are usually simulated through numerical approaches due mainly to the technical difficulties and high costs associated with experimental tests. The consequences of bird impact can be severe and, therefore, the aircraft components have to be certified for a proven level of bird impact resistance before being put into service.

Bird impact poses serious threats to military and civilian aircrafts as they lead to fatal structural damage to critical aircraft components. The exposed aircraft components such as windshields, radomes, leading edges, engine structure, and blades are vulnerable to bird strikes.

Among a large number of structural tests an aircraft structure needs a certification requirement for a proven level of impact resistance against bird impacts. Bird strike experiments are very expensive and henceforth explicit numerical modeling techniques have grown importance. Parts of aircraft construction are intensively vulnerable to damage during flight by bird impact. The theoretical approach and results of numerical simulations of dynamic response of the wing loaded by the bird impact are presented. The numerical simulation is carried out using smooth particle hydrodynamics (SPH) method running in the nonlinear explicit finite element code ANSYS AUTODYN. The focus is given to the validation of the stress, strain and deflection of wing on the impact zone. The dependency of given parameters on the variation of ellipsoidal bird aspect ratio, impact velocity and wing design details was discussed. As well, some results of experimental data were given. The behavior of aircraft leading edge against high speed bird impact was successfully simulated and the effect of various parameters on its dynamic response was studied. Numerical model was validated with published experimental results and further employed to investigate the influence of various parameters on dynamic behavior of of aircraft leading edge.

Keywords: aircraft wing structure, leading edge, impact birds, numerical simulations, SPH model, finite element method

\section{INTRODUCTION}

Among a large number of structural tests an aircraft structure needs a certification requirement for a proven level of impact resistance against bird impacts. Bird strike experiments are very expensive and henceforth explicit numerical modeling techniques have grown importance $[1,2,6]$.

High velocity bird impact is one of the most significant hazards to both civilian and military aircrafts [12]. When fighter military aircrafts are operated at lower altitude and higher speed, the probability of bird impact increases and proves lethal to the safety of pilot and critical aircraft components.

In order to ensure the safety of aircraft, the leading edge wing must be capable of leading edge wing high velocity impact threats. Design of an optimum impact

Received: May 2014, Accepted: December 2014

Correspondence to: Prof Stevan Maksimović

Military Technical Institute

Ratka Resanovića 1, 11132 Belgrade, Serbia

E-mail: s.maksimovic@open.telekom.rs resistant leading edge wing is a challenge and requires extensive experimental testing.

The advanced numerical techniques are being adopted as an effective tool to simulate the bird strike event and provide a substitute to excessive costly experimentations. Moreover, it allows analyzing the most stringent impact conditions that cannot be considered in the experiments and provides detailed insight to the impact process which is difficult to observe during experimental testing.

The design methodology followed in the development of the typical wing leading-edge is to have skin, transversal ribs, longitudinal stiff, and baffle plates, which will prevent the bird from impacting the front spar in the case of penetration of the wing skin. As a Type A, a wing leading-edge profile consisting of nose box skin, baffle, stiff and two side ribs is selected for this purpose (Fig. 1). Radius of leading-edge profile is $90 \mathrm{~mm}$ and $\mathrm{L} / \mathrm{H}$ ratio is 2 . A wing section of a Type $B$ consists of wing skin and four transversal ribs. Radius of leading-edge profile is $40 \mathrm{~mm}$ and $\mathrm{L} / \mathrm{H}$ ratio is 3 . Aluminium alloys were used for skin, ribs and stiff, and baffle was designed using kevlar-epoxy composites. In 
all cases the thickness of skin was fixed at $2.5 \mathrm{~mm}$ and thickness of other parts at $4 \mathrm{~mm}$. The Lagrangian technique was used to model the wing.

The artificial bird models would replace real birds in actual impact simulations. The accurate modeling of an "artificial" bird includes the shape and material modeling of the bird. In this work the ellipsoidal bird geometry is considered for the finite element bird simulation. The homogenous gas-water mixture was accepted for bird material [3].

Measured masses and dimensions of several kinds of actual bird species are illustrated in Table 1. Majority of the birds responsible for damage in a bird strike are medium sized (1.5 to $2.5 \mathrm{~kg}$ ).

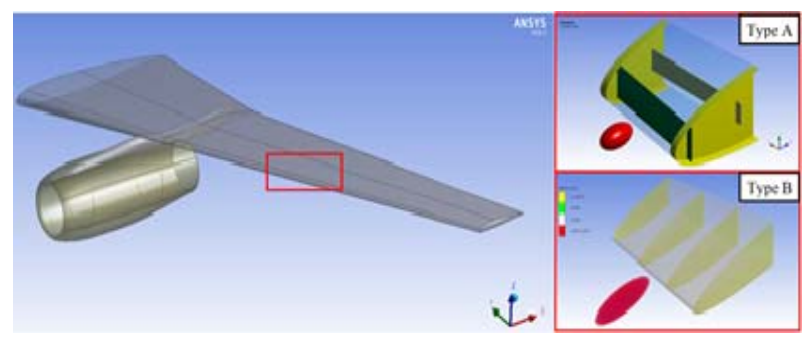

Figure 1. 3D Models of aircraft wing and considered types of wing sections (Type $A$ - boundary box: $600 \times 600 \times 300 \mathrm{~mm}$ and Type B - boundary box: $600 \times 600 \times 200 \mathrm{~mm}$ )

The basic goals of the research presented in this work can be summarized as follows:

- numerical simulation of various cases of bird impacts including the variation of bird aspect ratio, impact velocity and types of the wing section and

- validation of the structural response of a leading edge when subjected to bird strikes.

The numerical simulation is carried out using SPH method running in the finite element code ANSYS AUTODYN $^{\circledR}[4]$.

Table 1. Mean initial mass, density and length to diameter ratio of 7 specimens of birds

\begin{tabular}{|c|c|c|c|c|}
\hline \multirow{2}{*}{ Species } & \multirow{2}{*}{$\begin{array}{l}\text { Initial } \\
\text { mass }\end{array}$} & \multicolumn{2}{|c|}{ Density } & \multirow{2}{*}{$l / d$ ratio } \\
\hline & & Dry & Wet & \\
\hline- & [g] & {$\left[\mathrm{g} / \mathrm{cm}^{3}\right]$} & {$\left[\mathrm{g} / \mathrm{cm}^{3}\right]$} & - \\
\hline Starling & $72 \pm 5$ & $0.776 \pm 0.035$ & $0.947 \pm 0.024$ & $4.6 \pm 0.3$ \\
\hline $\begin{array}{l}\text { House } \\
\text { sparrow }\end{array}$ & $23 \pm 2$ & $0.751 \pm 0.042$ & $0.913 \pm 0.035$ & $4.6 \pm 0.2$ \\
\hline Mallard & $\begin{array}{c}1329 \pm \\
151\end{array}$ & $0.739 \pm 0.040$ & $0.877 \pm 0.026$ & $6.0 \pm 0.3$ \\
\hline $\begin{array}{l}\text { Turkey } \\
\text { vulture }\end{array}$ & $\begin{array}{c}1857 \pm \\
165 \\
\end{array}$ & $0.700 \pm 0.018$ & $0.803 \pm 0.024$ & $4.1 \pm 0.2$ \\
\hline $\begin{array}{l}\text { Laughing } \\
\text { gull }\end{array}$ & $322 \pm 27$ & $0.700 \pm 0.043$ & $0.831 \pm 0.027$ & $5.2 \pm 0.2$ \\
\hline $\begin{array}{l}\text { Canada } \\
\text { goose }\end{array}$ & $\begin{array}{c}3976 \pm \\
710 \\
\end{array}$ & $0.669 \pm 0.041$ & $0.807 \pm 0.023$ & $5.8 \pm 0.5$ \\
\hline $\begin{array}{l}\text { Rock } \\
\text { dove }\end{array}$ & $323 \pm 46$ & $0.648 \pm 0.032$ & $0.802 \pm 0.020$ & $4.0 \pm 0.2$ \\
\hline
\end{tabular}

According to the Federal Aviation Regulation (FAR 25.571) an airplane must be capable of successfully completing the flight during which likely structural damage might occur as result of impact with $1.81 \mathrm{~kg}$ (4 lb) bird at cruise velocity at the sea level. In Table 1.1 the mass of bird for certification requirements on different aircraft parts is specified with section numbers of Federal Aviation Regulation.

Table 1.1 Bird Strike Requirements [8]

\begin{tabular}{|c|c|c|}
\hline Part & Bird mass & FAR \\
\hline Leading Edge Wing & $1.81 \mathrm{~kg}$ & 25.571 \\
\hline Leading Edge Empennage & $3.62 \mathrm{~kg}$ & 25.631 \\
\hline Windshield & $1.81 \mathrm{~kg}$ & 25.775 \\
\hline Engine & $1.81 \mathrm{~kg}$ & 25.571 \\
\hline
\end{tabular}

The present work aims to numerically model the impact response of wing leading-edge and examine the effect of various factors that contribute to optimize the design of certain wing leading-edge. The certification requirements for leading edges of wing and empennage structure for the aircraft under consideration in this study are based on FAR 25.571 and 25.631 respectively. The leading edges of wing and empennage structures of an aircraft are susceptible to damages induced as a result of bird strikes. Therefore in addition to the aerodynamic functions, it needs to protect the supporting spars and control surfaces in case of such events. The bird strike damages to the leading edges can result in serious damages to the control rods (in case of wings) and control surfaces like elevator (in case of horizontal stabilizer) and rudder (in case of vertical stabilizer). Hence the approach to the design of leading edges for bird strike will be to have a leading edge with improved energy absorption capability which transfers lesser reaction forces to the supporting structures like spars. Since leading edge is the front part of these structures, a careful design to maximise the energy absorption is followed to ensure less damages to supporting structures.

Several critical factors such as mass and shape of bird, impact velocity, angle of impact, and impact location were studied and their influence on the dynamic response of wing leading-edge was assessed. The numerical model was developed and implemented in explicit finite element hydro code ANSYS AUTODYN.

The definition of a suitable bird model is often the main problem in the numerical simulation of bird strike incidents. Starting with relatively simple nonlinear calculations and a pressure load applied to the target structure in the 1970s, complex fluid-structure interactions are treated today with explicit simulation codes and high performance computing. Most interestingly, this evolution from simple to complex and accurate methods did not lead to the establishment of one generally accepted bird impactor modeling approach. Instead, there are still at least three techniques today, which are widely used, each having its own advantages and disadvantages (Lagrangian, Eulerian and meshless particle modeling (SPH)). A comprehensive overview of these bird strike modeling methods can be found in reference [11].

Although the certification of bird-strike resistant aircraft components still depends on real physical tests, proposals are increasingly put forward to use more simulation techniques instead of experiments in certain well-defined scenarios $[9,10]$. 


\section{AIRCRAFT SERTIFICATION STANDARDAS (BIRD STRIKE DESIGN CRITERION)}

The nature of aircraft damage from bird strikes, which is significant enough to create a high risk to continued safe flight, differs according to the size of aircraft. Bird strike is common and can be a significant threat to aircraft safety. For smaller aircraft, significant damage may be caused to the aircraft structure and all aircraft, especially jet-engined ones, are vulnerable to the loss of thrust which can follow the ingestion of birds into engine air intakes. This has resulted in a number of fatal accidents. The nature of aircraft damage from bird strikes, which is significant enough to create a high risk to continued safe flight, differs according to the size of aircraft. Small, propeller-driven aircraft are most likely to experience the hazardous effects of strikes as structural damage, such as the penetration of flight deck windscreens or damage to control surfaces or the empennage. Larger jet-engined aircraft are most likely to experience the hazardous effects of strikes as the consequences of engine ingestion.

The primary defence against hazardous bird strikes stems from the requirements for continued safe flight after strikes which are included in the airworthiness requirements of the Aircraft Type and Aircraft Engine Type Certification processes. However, these requirements are not a complete protection and are also mainly focussed on large fixed wing transport aircraft. The relevant design requirements for smaller fixed wing aircraft and helicopters are very limited.

Bird strike is a significant design criterion for leading edges of wing and empennage structures. The certification clauses demand that the aircraft be able to successfully land after the leading edges being struck with a standard bird at cruise velocity of the aircraft for a given altitude. Therefore, the approach followed in the design of leading edges for bird strike is to have a leading edge with improved energy absorption capability which transfers lesser reaction forces to the supporting structures like spars. Since leading edge is the front part of these structures, a careful design to maximise the energy absorption is followed to ensure less damages to supporting structures. In this aspect, a parametric study can help in identifying the parameters which influence the impact behaviour of the leading edges during bird impact.

Current standards for the impact of a single bird with a large aircraft airframe exist in both 14 CFR Part 25571 and in EASA CS-25.631 as design requirements for which means of compliance are provided. This is that an aeroplane must be capable of continued safe flight and landing after hitting a $1.8 \mathrm{~kg}$ bird at the more critical of: $\mathrm{Vc}$ (cruise speed) at mean sea level or $85 \%$ of $\mathrm{Vc}$ at 8000 feet altitude. The FAA (only) has an additional requirement under 14 CFR Part 25-631 that an aeroplane must be capable of continued safe flight and a subsequent normal landing after the empennage structure has been impacted by an $3.6 \mathrm{~kg}$ bird at cruise speed (Vc) at mean sea level. In addition, both EASA CS-25 and 14 CFR Part 25 require that: Windshield integrity after single bird impact requires that the inner ply must be non-splintering and the panes directly in front of the pilots must withstand, without penetration, a $1.8 \mathrm{~kg}$ bird at cruise speed at mean sea level. Pitot Tube must be far enough apart to preclude damage from a single bird impact. Under EASA CS-23.775 and 14 CFR Part 23.775, smaller aircraft are required only to have limited windshield integrity - a demonstrated single bird impact resistance of up to $0.91 \mathrm{~kg}$ at maximum approach flap speed and at least one pane with sufficient forward vision remaining to allow continued safe flight. Under 14 CFR Part 29-631, Helicopters are required only to have a structure which will ensure that continued safe flight and landing is possible after impact with a single bird of up to $1 \mathrm{~kg}$ weight at the lesser of $\mathrm{Vne}$ and $\mathrm{V}_{\mathrm{h}}$ at 8000 feet above mean sea level.

\section{THEORETICAL ASPECTS}

Numerical simulation of dynamic loading problems understand finding the new state of continuum $\{\rho, \vec{u}, t\}\left(\vec{r}, t>t_{0}\right)$ for initial value of given relation $\{\rho, \vec{u}, t\}\left(\vec{r}, t_{0}\right)$ over some region $\{\vec{r}\}$ for $\vec{r} \in \mathfrak{R}[4]$. Transition of continuum in the Lagrangian coordinates is described by the partial differential equations of the conservation of mass, momentum and energy. These, together with the equations of material state and a set of initial and boundary conditions, define the complete solution of the problem. Material continuum in a Lagrangian grid moves and distorts during time automatically satisfying the above mentioned equations. Neglecting heat conduction, the Lagrangian continuum equations are:

$$
\begin{gathered}
\frac{\partial \rho(\vec{r}, t)}{\partial t}=-\rho(\vec{r}, t) \operatorname{div} \vec{u}(\vec{r}, t) \\
\frac{\partial \vec{u}(\vec{r}, t)}{\partial t}=-\frac{1}{\rho(\vec{r}, t)} \operatorname{grad} p(\vec{r}, t) \\
\frac{\partial e(\vec{r}, t)}{\partial t}=-p(\vec{r}, t) \operatorname{div} \vec{u}(\vec{r}, t)
\end{gathered}
$$

Model geometry, initial velocities $\vec{u}(\vec{r}, t)$ and external loads $p(\vec{r}, t)$ for $\{\vec{r}\} \in \mathfrak{R}$ determine the initial and boundary conditions. The pressure $p$ is related to the density $\rho$ and specific internal energy $e$ through the equation of state given in general form.

$$
p=f(\rho, e)
$$

The equation of state $f(\rho, e)$ completes the system of equations (1)-(3) and allows integration to proceed.

Smooth Particle Hydrodynamics (SPH) formulation is a mesh-less Lagrangian technique used to model the fluid equations of motion using a pseudo-particle interpolation method to compute smooth hydrodynamic variables [4]. In this formulation, the fluid is represented as a set of moving particles, each one representing an interpolation point, where all the fluid properties are known. These particles have a spatial distance (so-called "smoothing length", represented in equations by h), over which their properties are "smoothed" by a kernel function. The contributions of each particle to a 
property are weighted according to their distance from the particle of interest, and their density. Mathematically, this is governed by the kernel function (symbol W). The equation for any quantity A at any point $r$ is given by the equation (2):

$$
A(r)=\sum_{j=1}^{n} m_{j} \frac{A_{j}}{\rho_{j}} W\left(\left|r-r_{j}\right|, h\right)
$$

where $m_{j}$ is the mass of particle $j, A_{j}$ is the value of the quantity $A$ for particle $j, \rho_{j}$ is the density associated with particle $j$, and $r$ denotes position and $W$ is the kernel function. $\mathrm{W}$ is the kernel function which is a function of the smoothing length and the position of the relevant particles.

The contribution of each particle to the particle of interest is weighted by the kernel function. The SPH processor in ANSYS AUTODYN uses a variable smoothing length, keeping the same number of particles in the neighborhood of the particle of interest. Using a variable smoothing length optimize the computation in the region of interest whereby the smoothing length is decrease for denser region and vice versa. For the SPH bird model, the scale factor for the maximum and minimum smoothing length is set at 0.2 and 2 respectively.

\section{FEM MODELING}

This work basically deals with the studies on the leading edges of wing structures of a typical aircraft. In the present study, finite element (FE) simulations were performed to assess the dynamic response of aircraft leading edge against high velocity bird impact. Numerical simulations were performed by developing nonlinear FE model in commercially available explicit FE solver AUTODYN. An elastic-plastic material model coupled with maximum principal strain failure criterion was implemented to model the impact response of aircraft leading edge.

Regarding selection of the "artificial" bird material there the porous water was accepted with porosity $\mathrm{z}=$ 0.2 .

The effect of porosity with the P-alpha EOS for porous material was investigated [3].

The appropriate mechanical parameters of the waterair mixture depending on porosity are given in Table 2 .

The mechanical parameters of considered ellipsoidal bird geometry depending on a length-to-diameter ratio are shown in Table 3.

The ellipsoidal bird models had a total of 1016 to 15614 SPH particles.

Table 2. Mechanical parameters of the water-air mixture

\begin{tabular}{|c|c|c|c|c|}
\hline $\begin{array}{c}\text { Porosity, } \\
z\end{array}$ & $\begin{array}{c}\text { Reference } \\
\text { density, } \\
\rho_{\text {ref }}\end{array}$ & $\begin{array}{c}\text { Density, } \\
\rho\end{array}$ & $\begin{array}{c}\text { Sound } \\
\text { speed, } c_{p}\end{array}$ & $\begin{array}{c}\text { Bulk } \\
\text { modulus, } \\
K\end{array}$ \\
\hline- & {$\left[\mathrm{kg} / \mathrm{m}^{3}\right]$} & {$\left[\mathrm{kg} / \mathrm{m}^{3}\right]$} & {$[\mathrm{m} / \mathrm{s}]$} & {$[\mathrm{MPa}]$} \\
\hline 0.2 & 1000.0 & 800.25 & 1256 & 1260 \\
\hline
\end{tabular}

Both type of wing sections (A and B) were modelled as Lagrangian structures assuming all degrees of freedom of wing structure unconstrained. The single layered wing components were a sheet of aluminium alloy. The material law used for the aluminium alloy was an isotropic elastic plastic model with mechanical parameters given in Table 4.

Table 3. Mechanical parameters of "artificial" bird

\begin{tabular}{|l|c|c|c|c|c|c|c|}
\hline Type & $\begin{array}{c}\text { Ratio } \\
, l / d\end{array}$ & $\begin{array}{c}\text { Diam } \\
\text { eter, } d\end{array}$ & $\begin{array}{c}\text { Length, } \\
l\end{array}$ & $\begin{array}{c}\text { Poros } \\
\text { ity, } z\end{array}$ & $\begin{array}{c}\text { Density } \\
, \rho\end{array}$ & $\begin{array}{c}\text { Volu } \\
\text { me, } V\end{array}$ & $\begin{array}{c}\text { Mass, } \\
m\end{array}$ \\
\hline $\begin{array}{l}\text { Elips } \\
\text { oid }\end{array}$ & - & {$[\mathrm{m}]$} & {$[\mathrm{m}]$} & - & {$\left[\mathrm{kg} / \mathrm{m}^{3}\right]$} & {$\left[\mathrm{m}^{3}\right]$} & {$[\mathrm{kg}]$} \\
\hline Midle & $2: 1$ & 0.125 & 0.250 & 0.2 & 800.25 & $\begin{array}{c}0.002 \\
0048\end{array}$ & $\begin{array}{c}1.604 \\
3\end{array}$ \\
\hline Midle & $4: 1$ & 0.100 & 0.400 & 0.2 & 800.25 & $\begin{array}{c}0.002 \\
0968\end{array}$ & $\begin{array}{c}1.678 \\
0\end{array}$ \\
\hline
\end{tabular}

Table 4. Mechanical parameters of Al alloy wing structure

\begin{tabular}{|c|c|c|c|c|c|c|}
\hline Density & $\begin{array}{c}\text { Poisson's } \\
\text { ratio }\end{array}$ & $\begin{array}{c}\text { Young's } \\
\text { modulus }\end{array}$ & $\begin{array}{c}\text { Shear } \\
\text { modulus }\end{array}$ & $\begin{array}{c}\text { Tensile } \\
\text { yield } \\
\text { strength }\end{array}$ & $\begin{array}{c}\text { Ultimate } \\
\text { strength }\end{array}$ & $\begin{array}{c}\text { Failure } \\
\text { strain }\end{array}$ \\
\hline $\mathrm{kg} / \mathrm{m}^{3}$ & - & $\mathrm{GPa}$ & $\mathrm{GPa}$ & $\mathrm{MPa}$ & $\mathrm{MPa}$ & $\%$ \\
\hline 2.785 & 0.33 & 71.00 & 28.60 & 280.00 & 385 & 18 \\
\hline
\end{tabular}

\section{RESULTS AND DISCUSSION}

Numerical simulation of various cases of bird impacts for two types of wing sections was accomplished. Final stages of the impact even for ellipsoidal bird of $100 \mathrm{~m} / \mathrm{s}$ velocity after $4.0 \mathrm{~ms}$ of process are presented in Fig. 2 .

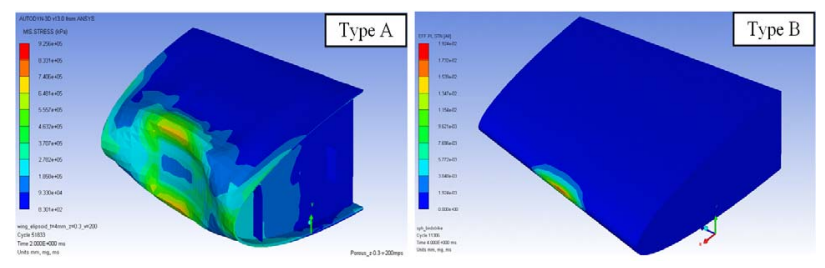

Figure 2. Total deformation and effective plastic strain of wing sections at $100 \mathrm{~m} / \mathrm{s}$ impact velocity ( $t=4 \mathrm{~ms})$

Analysis of the above structural appearance depicts significant difference in deformations of given models. Deflection of impact zone in the case of Type B is negligible due to appropriate geometry and higher stiffness of design. Increasing impact velocity would allow more appropriate characterization of the wing deformations. In this way the impact velocity for wing Type B was varied from $100 \mathrm{~m} / \mathrm{s}$ to $200 \mathrm{~m} / \mathrm{s}$ at the same all other conditions. Appearance of maximum wing skin deflection in the impact zone and effective plastic strain are shown in Fig. 3 (left). The dependency of maximum wing skin deflection on impact velocity is given in the same figure (right).
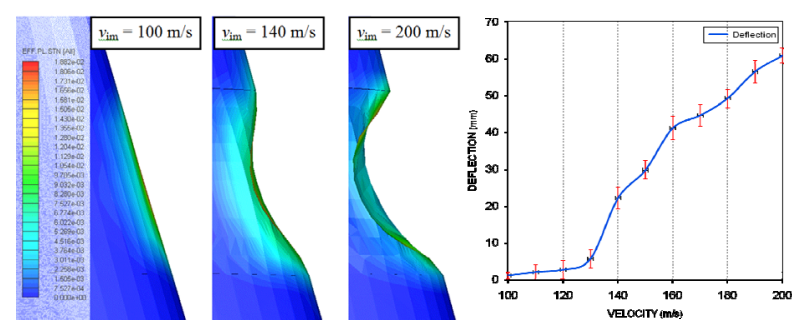

Figure 3. Maximum deflection and effective plastic strain depending on impact velocity (Type B)

According the results of numerical simulations the first more serious leading-edge deflections of wing Type B appear at $130 \mathrm{~m} / \mathrm{s}$ impact velocity and higher. 
Typical history diagrams of gauge point deflection (displacement along vector velocity) on leading-edge of wing Type A for impact velocities of 100 and $150 \mathrm{~m} / \mathrm{s}$ are shown in Fig. 4.
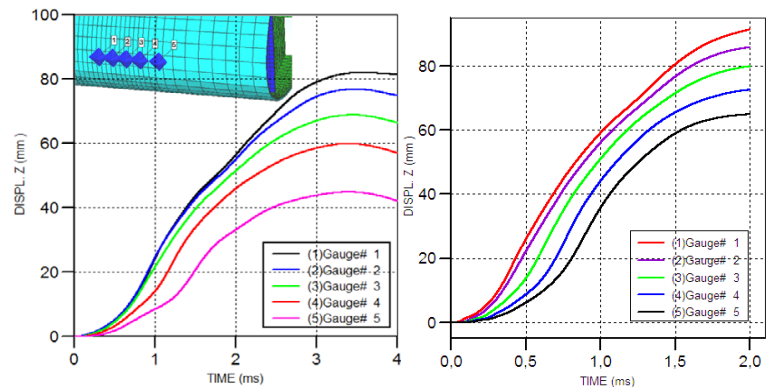

Figure 4. Deflection of central impact zone on wing Type $A$ at $v_{\text {im }}=100 \mathrm{~m} / \mathrm{s}$ (left) and $v_{\text {im }}=150 \mathrm{~m} / \mathrm{s}$ (right)

The relevant results of numerical simulation of effect of the bird aspect ratio $1 / \mathrm{d}$ for wing Type B at 200 $\mathrm{m} / \mathrm{s}$ impact velocity are given in Fig. 5 .
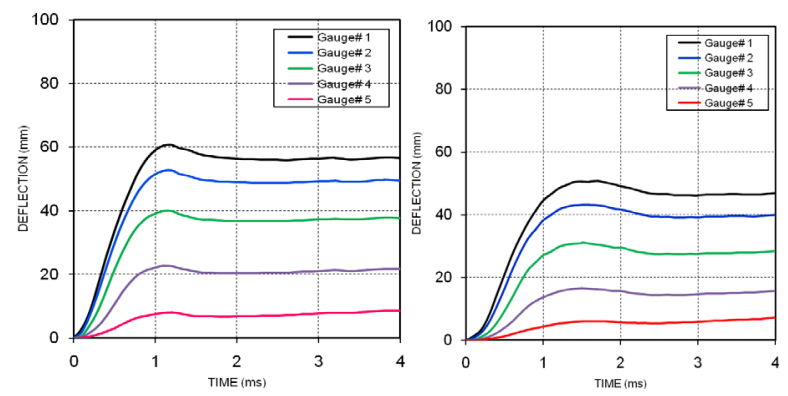

Figure 5. Deflection of wing skin Type B at $v_{\mathrm{im}}=200 \mathrm{~m} / \mathrm{s}$ with $/ / d=2$ (left) and with $/ / d=4$ (right)

Regarding the bird aspect ratio the deflection of points on the impact zone decreases growing the ratio 1/d. Maximum deflection achieves after the impact duration or so-called bird "squash-up" time 1/vim (e.g.: for $1 / \mathrm{d}=2,1 / \mathrm{vim}=0.25 / 200=1.25 \mathrm{~ms}$ ). Further progress depicts decreasing the maximum deflection due to residual elastic stress in the material.

The real impact understands bird velocity negligible, but more frequently in the numerical simulations the airplane velocity can be assumed for the bird. Both situations were simulated and relative error of maximum deflection during time at $200 \mathrm{~m} / \mathrm{s}$ impact velocity is shown in Fig. 6 (left). As well, Fig. 6 (right) depicts the results of experiment [5] and numerical simulation of leading edge deflection of $3.2 \mathrm{~mm}$ wing thickness after the large bird strike (bird mass: $3.63 \mathrm{~kg}$ ) at an impact speed of $125 \mathrm{~m} / \mathrm{s}$.

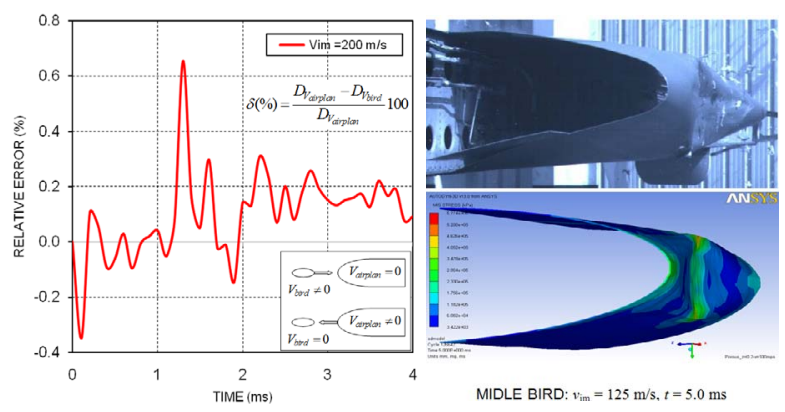

Figure 6. Relative error of maximum deflection at vim $=\mathbf{2 0 0}$ $\mathrm{m} / \mathrm{s}$ for moving wing an moving bird (left); Comparison of real test and numerical simulation of wing skin deformation at $v_{\text {im }}=125 \mathrm{~m} / \mathrm{s}$ (right)
Relative error of wing deflection during impact time is always less than $0.7 \%$, so it can consider impact event practically independent on the above mentioned impact scenarios. On the other side, the comparison of the real test and numerical simulation shows a very good agreement between the experimental and the simulated bird strike event.

\section{CONCLUSIONS}

In aircraft engineering there is a strong interest in reliable numerical methods for structural design under vulnerability aspects to reduce testing expenses and development time.

The aim of this work is to develop a methodology which can be utilized to certify an aircraft for bird strike using computation techniques since the physical testing of bird strike is expensive and time consuming.

The behavior of wing leading-edge against high speed bird impact was successfully simulated and the effect of various parameters on its dynamic response was studied. This work considers numerical simulation of bird strike to aircraft wing structure. The numerical simulation is carried out using smooth particle hydrodynamics (SPH) method running in the nonlinear explicit finite element code ANSYS AUTODYN. This investigation included the next activity to study bird strike of aircraft wing structure:

- The qualitative and quantitative determination of the stress and deformation state in the jet material was carried out by finite element method.

- The available finite element formulations by SPH technique approach and material laws for bird strike modeling have been assessed.

- Validation of the structural response of a leading edge when subjected to bird strikes showed good correlations with the experimental data reported in the literature.

- The numerical simulation of various cases of bird impacts including the variation of bird aspect ratio, impact velocity and types of the wing section were carried out successfully.

- The developed numerical models comprise a useful tool for the analysis of the failure mechanisms and damage propagation of a bird strike scenario.

The validated SPH bird model is impacted on the leading edge of aircraft wing. Further ongoing work in order to increase the predictability and reliability of bird impact simulations on aircraft structures aims at accurate aircraft damage models for explicit

calculations and the standardization of a substitute bird impactor.

\section{ACKNOWLEDGMENT}

Parts of this research were supported by the Ministry of Education and Science of the Republic of Serbia through the Mathematical Institute SANU Belgrade Grant OI 174001 "- Dynamics of hybrid systems with complex structures, Mechanics of materials" and project TR 35011. The authors would like to thank Dr 
Milan Bojanović, Director of CAD PROFESSIONAL SYS, for their support of the research and facilitate the use of licensed academic software ANSYS products.

\section{REFERENCES}

[1] Meo M., Vignjević R., Maengo M.: Numerical Simulations of Low-Velocity Impact on an Aircraft Sandwich Panel, Composite Structures, Vol. 62, pp. 353-360, 2003.

[2] Guida M., Marulo F., Meo M., Grimaldi A., Olivares G., SPH - Lagrangian study of bird impact on leading edge wing, Compos. Struct. 93 (2011) 1060-1071.

[3] Ugrčić M.: Application of the Hydrodynamic Theory and the Finite Element Method in the Analysis of Bird Strike in a Flat Barrier, Scientific Technical Review, Vol. 62, No. 3-4, pp. 28-37, 2012.

[4] ANSYS AUTODYN User's Manual Theoretical manual, ANSYS Inc. Southpointe, 275 Technology Drive, Canonsburg, PA, USA, 2010.

[5] Guida M., Meo M., et al.: Transient Three Dimensional Finite Element Analysis of a Bird strike on a Sandwich Fin Leading Edge, 7th International conference on composite science and technology, American University of Sharjah, Sharjah, United Arab Emirates, 2009.

[6] Ugrčić M., Maksimović S.: Critically Shaped Charge Jet Stress Caused by Angular Velocity, Facta Universitatis series: Mechanics, Automatic Control and Robotics, 2007, vol. 6, No. 1, pp. 119-130.

[7] Ugrčić M., Maksimović S., Stamenković D., Finite Element Modeling of Wing Bird Strike, $1^{\text {st }}$ Int Symposium on Machines, Mechanics and Mechatronics - Current Trends, Serbia, University Belgrade, Faculty of Mechanical Engineering, July 1-2, 2014.

[8] Thorpe, J., Fatalities and Destroyed Civil Aircraft due to Bird Strikes, international Bird Strike Committee, 2003.

[9] McCarthy MA, Xiao JR. Modeling of bird strike on an aircraft wing leading edge made from fiber metal laminate - Part 2: modeling of impact with SPH bird model. Applied Composite Materials, 2004;11(6):317-40.

[10] Heimbs, S., Computational methods for bird strike simulations: a review, Comput Struct 2011;89(2324):2093-112.

[11] Heimbs, S., "Bird Strike Analysis in Aircraft Engineering: An Overview ", In: Advances in Mechanical Engineering Research, Volume 3, D.E. Malach (ed.), Nova Science Publishers, New York, 2011.
[12] Thorpe, J., "Fatalities and destroyed civil aircraft due to bird strikes, 1912-2002," in Proceedings of the 26th Meeting of the International Bird Strike Committee, Warsaw, Poland, 2003.

\section{МОДЕЛИРАЊЕ УДАРА ПТИЦЕ У СТРУКТУРУ КРИЛА АВИОНА}

\section{М. Угрчић, С. Максимовић, Д. Стаменковић, К. Максимовић, N. Khettoi}

Догађаји везано за удар птице и дана представљају потенцијалну опасност за безбедност лета авиона.Овакви догађаји се обично симулирају нумеричким методама примарно због техничких потешкоћа и високе цене везано за експерименталне тестове. Последице удара птице у структуру авиона могу имати различите нежељене ефекте стога поједине компоненте структуре авиона треба да буду сертификоване са аспекта отпорности на удар птице пре но што се авион укључи у редовну експлоатацију. Удар птице има низ опасности како за војне тако и за цивилне авионе пошто исти могу довести до фаталних оштећења појединих битних компоненти авиона. Изложене компоненте структуре авиона попут стакала кабинских поклопаца, нападних ивица, структура мотора и лопатице су посебно осетљиве са аспекта удара птице. Поред великог броја тестова структуре авиона иста треба да буде тестирана и са аспекта отпорности на удар птице. Експерименти везано за удар птице су скупи те нумеричке симулације удара птице имају битан значај у процесу пројектовања и анализа чврстоће структуре авиона. Поједини делови структуре авиона су током лета често изложени оштећењима од удара птице. Стога су у оквиру овог рада презентована одређена теоријска разматрања као и саме нумеричке симулације динамичкох одговора структуре нападне ивице крила авиона на оптерећења од удара птице. Нумеричке симулације понашања структуре нападне ивице крила авиона су реализоване користећи софтверски пакет ANSYS AUTODYN који базира на примени методе коначних елемената. Пажња у раду је била усмерена на валидацију напона, деформација и померања структуре нападне ивице крила у зони удара птице. Разматрани су различити утицаји удара птице елипсоидалног облика на понашања структуре нападне ивице крила авиона. 